\title{
PENGARUH PEM BELAJARAN AKTIF DALAM MENINGKATKAN PRESTASI BELAJAR FISIKA PADA SISWA KELAS 2 SMU
}

\author{
Postalina Rosida ${ }^{1)}$ dan Titin Suprihatin ${ }^{2 * *}$ \\ ${ }^{122)}$ Fakultas Psikologi Universitas Islam Sultan Agung Semarang \\ ${ }^{*}$ E-mail : bunda_ulhaq@yahoo.com
}

\begin{abstract}
Abstrak
Tujuan pendidikan nasional adalah meningkatkan potensi peserta didik untuk menjadi manusia yang religious, bertakwa, mulia, sehat, terampil, kreatif, bebas, bertanggung jawab dan demokratis. Hal ini membutuhkan proses belajar yang optimal untuk mendukung pencapaian tujuan yang diharapkan, serta mendapatkan prestasi yang tinggi dan memusakan bagi perserta didik.

Tujuan penelitian ini adalah untuk menemukan pengaruh model pembelajaran terhadap peningkatan prestasi belajar bidang fisikan pada siswa SMU Sultan Agung 4 Semarang. Penelitian ini adalah penelitian eksprimen yang menggunakan dua kelompok subjek berbeda. Desain eksperimennya adalah Non Random Pre-test-Post-test Control group Design. Responden ekpserimen ini adalah 62 siswa SMU kelas dua yaitu 33 kelas A1 dan 29 siswa kelas A2 yang menempuh mata pelajaran fisika. Pemilihan kelas ini berdasarkan persamaan mata pelajaran dan guru yang mengajar secara parallel. Kelompok Al adalah kelompok control yang mnggunakan model pembelajaran konvensional. Kelompok A2 adalah kelompok eksperimen dengan menggunakan model pembelajaran aktif (active learning). Eksperimen dilaksanakan selama empat minggu dengan delapan kali pertemuan atau sekitar 480 menit.

Data primer pretest untuk dua kelompok menggunakan data nilai mid semester sedangkan data post-test menggunakan tes yang disusun berdasarkan materi yang diberikan selama eksperimen. Analisis data seslisih pre-test dan post-test (gained scores) dilakukan dengan metode independent sampel test.

Hasil analisis diperoleh nilai $t=3.103$ dan $p=0.003(p<0.01)$. hal ini menunjukan bahwa ada perbedaan yang signifikan antara kelompok control dengan kelompok eksperimen. Pada kelompok eksperimen ditemukan peningkatan yang signifikan sedangkan pada kelompok control hasil pre-test dan post-test relatif sama.
\end{abstract}

Kata kunci : Model pembelajaran aktif

\section{THE IMPACT OF ACTIVE LEARNING IN ENHANCING THE STUDENT'S PHYSICS LEARNING ACHIEVEM ENT AM ONG $2^{\text {ND }}$ GRADE}

\begin{abstract}
The objective of national education is promoting the learner's potency in order to become human being who is religious and devoted to God Almighty, noble, healthful, faithful, skilled, creative, independent, responsible and democratic citizen. Essentially, it is necessary to create the learning process optimally for supporting the expected objective. Such optimization is supposed to reach the learning achievement optimally and satisfactorily for learners.

The purpose of this research was to discover the impact of active learning model against the enhancement of the student's physics learning achievement on $2^{\text {nd }}$ grade of 4 Sultan Agung J unior High School Semarang. This research was experimental research utilizing two different subject groups in which the used design was Non-Randomized Pretest-Post-test Control Group Design. The participants in this research were in the amount of 62 students that consist of 33 A1 students and $29 A 2$ students of $2^{\text {nd }}$
\end{abstract}


grade of 4 Sultan Agung Junior High School Semarang and all of the students were participated in the physics subject of this research. This class selection was based on the parallel teachers who teach on the class level in the similar subject. The A1 students further were modelled as control group using conventional learning model while A2 students were modelled as experimental group using active learning as their learning model in the class. This research was conducted for four weeks in eight meeting times and eight treatment times, for \pm 480 minutes.

The primary data of this research were pre-test data of both groups taken from scores of physics subject on mid-term test whereas post-test data were acquired from test scores according to the learning material. These data were analyzed by independent sample t-test.

The result of this analysis indicated score of $t=3.103$ and $p=0,003(<0,01)$, so it can be indicated that active learning model is able to enhance very significantly the physics' learning achievement of $2^{\text {nd }}$ grade of 4 Sultan Agung Junior High School Semarang.

Keywords: active learning, learning achievement

\section{Pendahuluan}

Pendidikan pada dasarnya menjadi tolok ukur dari kualitas suatu bangsa. Keberhasilan dalam bidang pendidikan, akan membuat kualitas suatu bangsa mendapat pengakuan di seluruh dunia. Namun kenyataannya, kualitas pendidikan di Indonesia masih sangat memprihatinkan. Hal ini ditunjukkan dari data Balitbang tahun 2003 bahwa dari 146.052 SD di Indonesia ternyata hanya delapan sekolah saja yang mendapat pengakuan dunia dalam kategori The Primary Years Program (PYP). Dari 20.918 SM P di Indonesia ternyata juga hanya delapan sekolah yang mendapat pengakuan dunia dalam kategori The Middle Years Program (MYP) dan dari 8.036 SM A ternyata hanya tujuh sekolah saja yang mendapat pengakuan dunia dalam kategori The Diploma Program (DP). Menurut Al-Jawi (2006) makna data-data tentang rendahnya kualitas pendidikan Indonesia di atas menunjukkan adanya masalah dalam sistem pendidikan Indonesia. Ditinjau secara perspektif ideologis (prinsip) dan perspektif teknis (praktis), berbagai masalah itu dapat dikategorikan dalam 2 masalah: masalah mendasar, yaitu kekeliruan paradigma pendidikan yang mendasari keseluruhan penyelenggaran sistem pendidikan, dan masalah-masalah cabang, yaitu berbagai problem praktis atau teknis yang berkaitan dengan penyelenggaraan pendidikan, seperti mahalnya biaya pendidikan, rendahnya prestasi siswa, rendahnya sarana fisik, rendahnya kesejahteraaan guru, dan sebagainya.

Berdasarkan kategori di atas, penulis lebih fokus untuk membahas masalah rendahnya prestasi belajar siswa, karena dalam hal ini indikator yang paling mudah untuk melihat kecukupan pengetahuan siswa di sekolah adalah prestasi belajar mereka. Salah satu parameter keberhasilan yang dicapai siswa adalah prestasi belajar akademik. Hal tersebut dapat diraih melalui belajar, dan dengan belajar diharapkan individu dapat mengembangkan semua potensi yang ada semaksimal mungkin. Belajar membutuhkan dorongan, gairah, dan semangat. Tanpa semua itu, belajar menjadi hal yang membosankan, bahkan menjadi beban. Hal inilah yang menyebabkan banyak pelajar mengalami kesulitan dalam belajar dan berakibat pada prestasi belajar akademiknya (Widyastuti \& Kuswardani, 2008). Pencapaian prestasi belajar dipengaruhi oleh berbagai faktor. Salah satunya seperti yang diungkapkan oleh Syah (2001) bahwa faktor penting yang mempengaruhi pencapaian prestasi belajar yaitu faktor pendekatan belajar, yang merupakan strategi atau metode yang digunakan dalam belajar. 
Banyak peneliti dewasa ini yang mencoba untuk melakukan penelitian terhadap metode pembelajaran. Berdasarkan penelitian-penelitian terdahulu, banyak metode atau model pembelajaran yang dicoba untuk diteliti. Salah satunya adalah metode pembelajaran konvensional yang sering dijadikan sebagai pembanding untuk metode pembelajaran yang lain. Pembelajaran konvensional adalah pembelajaran yang kurang memperhatikan perbedaan individual anak didik dan didasarkan pada keinginan guru. Kondisi seperti ini mengakibatkan tidak diperolehnya ketuntasan dalam belajar, sehingga sistem belajar tuntas terabaikan. Hal ini membuktikan terjadinya kegagalan dalam proses pembelajaran di sekolah (Hartono, 2008).

Berdasarkan wawancara yang telah dilakukan pada 4 orang siswa dan 1 guru pengampu mata pelajaran fisika di SMP Islam Sultan Agung 4 Semarang, menunjukkan bahwa proses pembelajaran dalam mata pelajaran IPA masih menggunakan pembelajaran konvensional. Hal ini terlihat dari kurangnya aktifitas siswa saat proses belajar mengajar, siswa cenderung diam dan bahkan berbicara sendiri ketika guru menyampaikan materi. Keadaan ini menunjukkan bahwa suasana proses belajar mengajar kurang menyenangkan sehingga siswa mencari kesenangan sendiri daripada hanya mendengarkan materi. Akibatnya berpengaruh pada prestasi belajar mereka yang kurang memuaskan. Rendahnya kompetensi siswa Indonesia khususnya pada mata pelajaran IPA dikarenakan tidak adanya proses pembelajaran yang bermakna yang mampu mengoptimalkan aspek-aspek perkembangan siswa sehingga pencapaian prestasinya pun tidak maksimal (Rosada \& Kumara, 2004). Menyadari kenyataan seperti ini para ahli berupaya untuk mencari dan merumuskan strategi yang dapat merangkul semua perbedaan yang dimiliki oleh anak didik. Strategi pembelajaran yang ditawarkan adalah strategi belajar aktif (active learning strategy) (Hartono, 2008).

Pembelajaran aktif (active learning) dimaksudkan untuk mengoptimalkan penggunaan semua potensi yang dimiliki oleh anak didik, sehingga semua anak didik dapat mencapai hasil belajar yang memuaskan sesuai dengan karakteristik pribadi yang mereka miliki (Hartono, 2008). Active learning (belajar aktif) pada dasarnya berusaha untuk memperkuat dan memperlancar stimulus dan respon anak didik dalam pembelajaran, sehingga proses pembelajaran menjadi hal yang menyenangkan, tidak menjadi hal yang membosankan bagi mereka. Dengan memberikan strategi active learning (belajar aktif) pada anak didik dapat membantu ingatan (memory) mereka, sehingga mereka dapat dihantarkan kepada tujuan pembelajaran dengan sukses. Hal ini kurang diperhatikan pada pembelajaran konvensional (Mulyasa dalam Hartono, 2008).

Berdasarkan latar belakang di atas, maka dapat dirumuskan suatu permasalahan yaitu seberapa besar pengaruh model pembelajaran active learning dalam meningkatkan prestasi belajar fisika?

Sesuai permasalahan yang telah diuraiakan di atas, maka tujuan penelitian ini adalah untuk mengetahui adanya pengaruh model pembelajaran active learning terhadap peningkatan prestasi belajar fisika pada siswa.

Menurut Winkel (1996) belajar adalah suatu aktivitas mental atau psikis yang berlangsung dalam interaksi aktif dengan lingkungan yang menghasilkan perubahan-perubahan dalam pengetahuan, pemahaman, ketrampilan dan sikap. Perubahan itu bersifat konstan dan 
berbekas, dalam hal ini apa yang terjadi pada individu yang sedang belajar tidak dapat diketahui secara langsung oleh orang lain, tetapi dapat diamati dari tingkah laku dan hasilnya.

Prestasi belajar adalah hasil yang dicapai seseorang dalam belajar. Prestasi belajar dalam bentuk nilai diperoleh melalui hasil pengukuran proses belajar (Suryabrata, 2004). Prestasi belajar adalah suatu hasil yang diperoleh siswa dalam usaha belajar yang dilakukannya dan merupakan produk dari suatu proses. Proses yang dilakukan individu adalah kegiatan belajar, prestasi belajar ini biasanya dinyatakan dalam bentuk nilai atau indeks prestasi yang diperoleh dari hasil pengukuran prestasi belajar (Widyastuti \& Kuswardani, 2008).

Surya (2004) menjelaskan bahwa inti dari seluruh kegiatan pendidikan terletak pada proses kegiatan belajar mengajarnya. Kegiatan belajar mengajar ini berlangsung melalui interaksi yang terjadi antar individu yaitu antara pengajar dengan anak didik, sehingga Surya membagi empat aspek penting dalam proses belajar mengajar berupa: (a) perilaku belajar siswa sendiri, (b) perilaku mengajar guru, (c) interaksi antara pengajar dan anak didik, dan (d) model pembelajaran.

Azwar (1999) merumuskan tentang faktor-faktor yang mempengaruhi prestasi belajar yaitu: 1. Faktor Internal, terdiri dari: faktor fisik (panca indra dan kondisi fisik umum) dan faktor psikologis (variabel non kognitif meliputi minat, motivasi, variabel kepribadian dan kemampuan kognitif meliputi kemampuan khusus atau bakat, kemampuan umum atau inteligensi); 2. Faktor Eksternal, terdiri dari: faktor fisik (kondisi tempat belajar, sarana dan perlengkapan belajar, materi pelajaran, dan kondisi lingkungan belajar) dan faktor sosial (dukungan sosial dan pengaruh budaya).

Mengenai masalah prestasi belajar, pencapaian prestasi fisika dan matematika siswa Indonesia di dunia Internasional sangat rendah. Menurut Trends in Mathematic and Science Study (TIM SS) pada tahun 2003, siswa Indonesia hanya berada di ranking ke-35 dari 44 negara dalam hal prestasi matematika dan di ranking ke-37 dari 44 negara dalam hal prestasi sains. Hal ini menunjukkan prestasi siswa Indonesia jauh di bawah siswa Malaysia dan Singapura sebagai negara tetangga yang terdekat (Al-Jawi, 2006). Berdasarkan beberapa riset menunjukkan bahwa secara konsisten metode pengajaran tradisional (konvensional), dimana guru berbicara dan siswa mendengarkan, telah mendominasi dunia pendidikan Indonesia (Rosada \& Kumara, 2004). Hal ini merupakan salah satu masalah yang menyebabkan pencapaian prestasi siswa Indonesia, khususnya pada mata pelajaran fisika masih sangat rendah. Oleh karena itu, untuk mencapai ketuntasan dalam belajar, guru harus menggunakan model pembelajaran yang tepat, dimana model pembelajaran itu harus dapat mengantarkan anak didik ke arah pencapaian tujuan pembelajaran dan dapat membangkitkan keaktifan anak didik ketika proses belajar mengajar. Salah satu model pembelajaran yang dapat meningkatkan keaktifan anak didik yaitu model pembelajaran aktif (active learning).

Active Learning merupakan istilah yang menunjukkan kegiatan belajar dimana siswa secara mental terlibat dalam suatu tugas. Ide dasarnya adalah bahwa siswa mendapat pengertian dalam belajar melalui interaksinya dengan lingkungannya, dan bahwa siswa dilibatkan dalam mengkonstruksi pengetahuan mereka (Kumara, 2004). Dalvi (2006) mengatakan pembelajaran aktif (active learning) sebagai suatu pendekatan dalam pembelajaran yang bermuara pada 
belajar mandiri, maka kegiatan belajar mengajar yang dirancang harus mampu melibatkan siswa secara aktif. Sehingga siswa tidak hanya sekedar mendengarkan informasi dari guru, akan tetapi juga melihat apa yang dijelaskan oleh guru dan kegiatan siswa yang terakhir adalah melakukan atau mencobanya secara langsung.

Prinsip-prinsip belajar siswa aktif meliputi anak didik harus lebih aktif dan berperan dalam semua aktivitas belajar, sedangkan guru hanya sebagai fasilitator yang bertugas mengarahkan proses belajar mengajar. Selain itu, menurut Ahmadi dan Supriyono (1991) ada beberapa prinsip belajar yang dapat menumbuhkan cara belajar aktif pada anak didik, yaitu stimulasi belajar, perhatian dan motivasi, respon yang dipelajari, penguatan, dan pemakaian dan pemindahan.

Pada penelitian ini, active learning merupakan suatu model pembelajaran yang mengacu pada berbagai macam metode pembelajaran. Salah satunya yaitu metode quiz team. Metode ini tidak saja dapat meningkatkan prestasi belajar siswa, tetapi juga dapat mengaktifkan siswa ketika di kelas. Sehingga suasana kelas saat proses belajar mengajar menjadi lebih menyenangkan. Pembelajaran quiz team merupakan salah satu pembelajaran aktif yang dikembangkan oleh M el Silberman (Dalvi, 2006) dimana siswa dibagi ke dalam tiga tim. Setiap siswa dalam tim bertanggung jawab untuk menyiapkan kuis jawaban singkat dan tim yang lain menggunakan waktu untuk memeriksa catatannya.

Semua anggota tim bersama-sama mempelajari materi tersebut, mendiskusikan materi, saling memberi arahan, saling memberikan pertanyaan dan jawaban untuk memahami mata pelajaran tersebut, setelah materi selesai diadakan suatu pertandingan akademis. Dengan adanya pertandingan akademis ini terciptalah kompetisi antar tim, para siswa akan senantiasa berusaha belajar dengan motivasi yang tinggi agar dapat memperoleh nilai yang tinggi dalam pertandingan (Nurhayati, 2007).

Penelitian ini menggunakan mata pelajaran IPA fisika sebagai materi dalam pembelajaran karena masih belum terpenuhinya standar ketuntasan belajar yang dicapai siswa, khususnya siswa kelas VIII SMP Islam Sultan Agung 4 Semarang. Fisika (Bahasa Yunani: physikos, "alamiah", dan physis, "Alam") adalah sains atau ilmu tentang alam dalam makna yang terluas. Fisika mempelajari gejala alam yang tidak hidup atau materi dalam lingkup ruang dan waktu (Wikipedia Indonesia, 2010). Fisika merupakan ilmu yang lebih banyak memerlukan pemahaman dari pada hapalan. Kunci kesuksesan dalam belajar fisika yaitu kemampuan untuk memahami tiga hasil pokok fisika yaitu; konsep-konsep atau pengertian, hukum-hukum atau asas-asas, dan teori-teori (Siregar, 2003).

Berdasarkan pada teori yang dikemukakan di atas, maka hipotesis yang diajukan dalam penelitian ini adalah: Terdapat pengaruh model pembelajaran active learning terhadap peningkatan prestasi belajar fisika pada siswa kelas VIII SM P Islam Sultan Agung 4 Semarang.

\section{Metode}

Penelitian ini melibatkan dua variabel yaitu: 1. Variabel Tergantung: Prestasi Belajar; 2. Variabel Bebas: Active Learning 
Penelitian ini merupakan penelitian eksperimen yang menggunakan dua kelompok subjek yang berbeda. Dimana desain eksperimen yang digunakan yaitu desain eksperimen ulang nonrandom (Non-Randomized Pretest-Posttest Control Group Design).

Tabel 1. Desain Eksperimen Ulang Non-Random(Non-Randomized Pretest-Posttest Control Group Design)

Kelompok Eksperimen nonR $O_{1} \rightarrow(\mathrm{X}) \rightarrow O_{2}$
Kelompok Kontrol nonR $O_{3} \rightarrow(-) \rightarrow O_{4}$

Penelitian tentang active learning ini mengacu pada metode Quiz team (kelompok kuis) yang diaplikasikan pada mata pelajaran fisika kelas VIII SM P Islam Sultan Agung 4 Semarang. Metode quiz team ini diawali dengan menerangkan materi pelajaran secara klasikal, lalu siswa dibagi ke dalam tiga tim besar. Semua anggota kelompok bersama-sama mempelajari materi tersebut, mendiskusikan materi, saling memberi arahan, saling memberikan pertanyaan dan jawaban untuk memahami materi tersebut. Setelah diskusi selesai, maka diadakan suatu pertandingan akademis. Dengan adanya pertandingan akademis ini dapat meningkatkan rasa tanggung jawab siswa atas apa yang mereka pelajari dengan cara yang menyenangkan, tidak monoton, dan tidak membosankan (Dalvi, 2006).

Pertandingan akademis dimulai oleh tim A sebagai pemandu kuis bagi tim B dan tim C. Soal kuis disediakan oleh tim A yang akan diajukan kepada tim B, jika tim B tidak mampu menjawab maka akan dilemparkan ke tim C, begitu seterusnya. Semua tim berkesempatan untuk menjadi pemandu kuis secara bergantian. Bila tim dapat menyelesaikan soal-soal tersebut dengan benar maka tim tersebut akan memperoleh nilai, demikian juga bila tim tersebut dapat menjawab pertanyaan dari soal tim lain yang tidak dapat dijawab oleh tim yang bersangkutan. Semua siswa mempunyai kesempatan yang sama untuk mengumpulkan nilai bagi kelompoknya. Setelah beberapa kali pertandingan, maka akan diperoleh tim yang keluar sebagai pemenang yaitu tim yang mencapai nilai paling tinggi dari tim lainnya (Dalvi, 2006).

Menurut Zaini, Munthe, dan Aryani (2007) alur active learning metode quiz team secara umum dapat digambarkan sebagai berikut: 


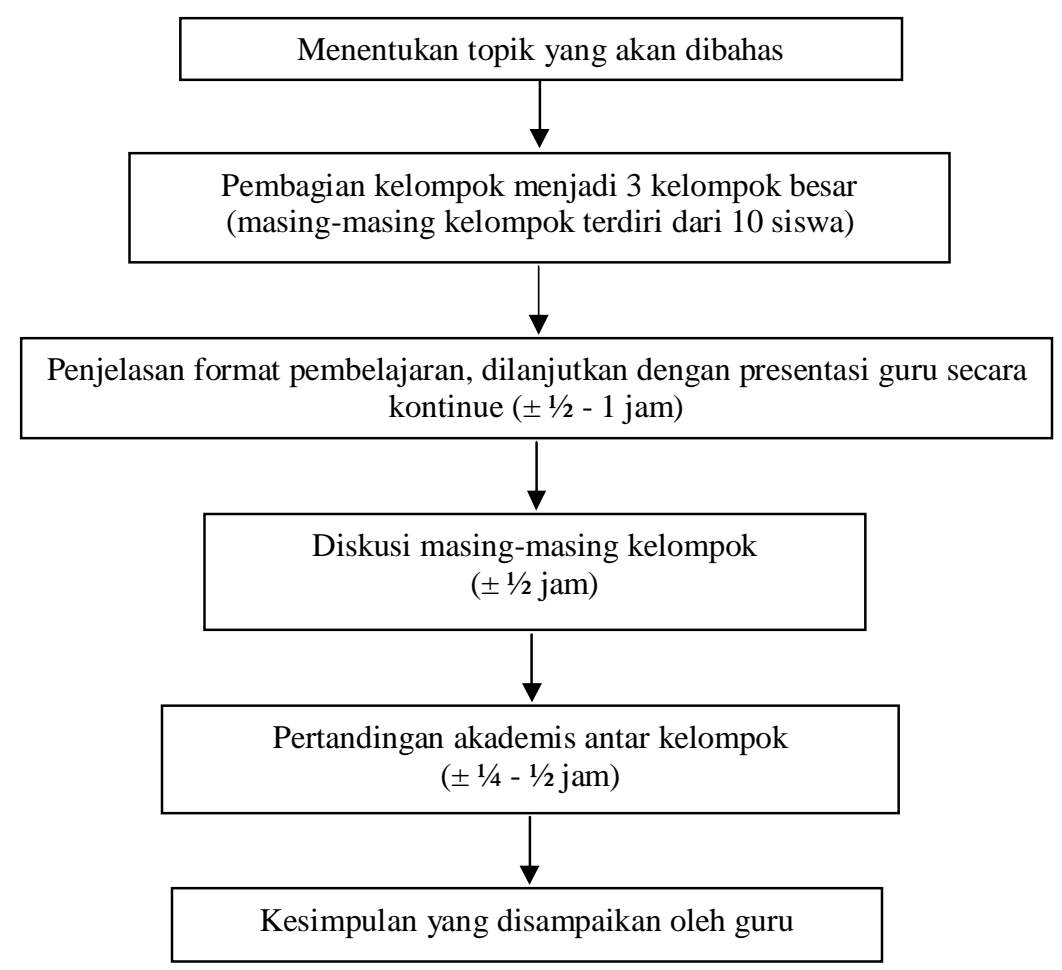

\section{Gambar 1. Alur Active Learning Metode Quiz Team}

Keterangan :

1. Menentukan topik yang akan dibahas. Topik ini terdiri dari tiga sub pokok bahasan.

2. Membagi siswa menjadi tiga kelompok besar (A, B, dan C).

3. Menyampaikan format pembelajaran kepada siswa, kemudian guru mulai mempresentasikan tiga sub pokok bahasan secara kontinue.

4. Diskusi kelompok untuk lebih memahami tiga materi yang telah disampaikan guru.

5. Dilanjutkan dengan pertandingan akademis antar kelompok, dimulai dengan kelompok A menyiapkan pertanyaan-pertanyaan berkaitan dengan materi pertama (sebagai kelompok penanya). Kelompok $B$ dan $\mathrm{C}$ menggunakan waktu ini untuk melihat lagi catatan mereka. M inta kelompok A untuk memberi pertanyaan kepada kelompok B. Jika kelompok $B$ tidak dapat menjawab pertanyaan, lempar pertanyaan tersebut kepada kelompok C. Kelompok A memberi pertanyaan kepada kelompok $C$, jika kelompok $C$ tidak bisa menjawab, lemparkan kepada kelompok B. Lanjutkan pertandingan sampai materi ketiga.

6. Akhiri pelajaran dengan menyimpulkan tanya jawab dan jelaskan sekiranya ada pemahaman siswa yang keliru. 
Partisipan dalam penelitian ini berjumlah 62 siswa, yang terdiri dari 33 siswa kelas VIII AI dan 29 siswa kelas VIII A2 SM P Islam Sultan Agung 4 Semarang yang seluruhnya diikutsertakan dalam penelitian pada mata pelajaran fisika semester genap tahun ajaran 2010/2011. Pemilihan kelas ini didasarkan pada paralelnya guru yang mengajar di dua kelas yang setingkat pada mata pelajaran yang sama. Siswa-siswa pada kelas Al selanjutnya dijadikan sebagai kelompok kontrol dengan menggunakan model pembelajaran konvensional. Sedangkan siswasiswa pada kelompok A2 dijadikan sebagai kelompok eksperimen, dengan menjadikan active learning sebagai model pembelajaran mereka di kelas. Penelitian ini dilaksanakan selama empat minggu dalam 8 kali pertemuan, dan 8 kali pemberian perlakuan, sekitar \pm 480 menit, yang dimulai pada 12 April 2011 sampai 14 M ei 2011.

Data dalam penelitian ini akan diambil melalui tes prestasi yang dilaksanakan sebelum dan sesudah adanya perlakuan (pre-test dan post-test). Data utama penelitian adalah data pre-test kedua kelompok yang diperoleh dari nilai fisika pada ujian tengah semester genap. Sedangkan, data post-test diperoleh dari nilai ulangan harian fisika sesuai materi yang dipelajari. Data-data ini dianalisis menggunakan independent sample t-test.

\section{Hasil}

Pelaksanaan pengajaran active learning pada kelompok eksperimen dilakukan dalam kelas reguler yang biasa mereka tempati dalam proses belajar mengajar sehari-hari sesuai jadwal yang telah ditentukan dari pihak sekolah. Sama halnya dengan kelompok kontrol juga dilaksanakan di kelas reguler dengan mengikuti jadwal belajar mengajar seperti biasa. Beberapa variabel ekstrane penting yang bisa dikontrol oleh peneliti adalah: a) kesetaraan tingkat kelas, b) mata pelajaran, c) materi yang diberikan dan d) kesamaan pengajar. Adapun variabel ekstrane yang tidak dapat dikendalikan oleh peneliti diantaranya adalah: a) menyamakan ruang penelitian, b) menyamakan jumlah siswa dimasing-masing kelas c) menyamakan waktu penelitian, d) kehadiran siswa secara utuh dalam beberapa pertemuan dan e) kegiatan siswa diluar kelas yang mungkin mempengaruhi pencapaian prestasi mereka.

Variabel ekstrane berupa menyamakan jumlah siswa antara kelompok eksperimen dan kelompok kontrol tidak dapat tercapai dikarenakan ada siswa yang pindah sekolah dan ada siswa baru yang masuk ketika pergantian semester. Hal ini tidak dapat di kontrol, karena peneliti tidak mempunyai hak untuk mengatur penempatan siswa tersebut.

Selain itu, menyamakan ruang dan waktu penelitian tidak dapat tercapai dikarenakan sekolah sudah menentukan ruangan sesuai dengan kelasnya masing-masing. Peneliti juga tidak dapat menyamakan waktu penelitian dikarenakan pihak sekolah sudah menentukan jadwal mata pelajaran fisika tersebut. Selain itu, jika ingin disamakan akan membutuhkan waktu dan bisa mengacaukan jadwal pelajaran yang lain. Menyamakan waktu penelitian ini juga tidak mungkin dilakukan karena akan mempengaruhi variabel lain yaitu kesamaan pengajar tidak mungkin dapat tercapai.

Peneliti dalam penelitian ini bekerja sama dengan pengajar dan tidak berinteraksi langsung dengan subjek penelitian namun hanya mengobservasi jalannya penelitian. Selama penelitian peneliti selalu berkomunikasi dengan pengajar guna menanyakan materi yang akan diberikan 
di kelas, mengontrol alur pengajaran dan mempersiapkan lembar-lembar diskusi serta kuiskuis yang akan dilaksanakan. Pengajar dalam penelitian ini berfungsi sebagai penyampai materi pada subjek dan peneliti berperan sebagai pendesain alur periodik pengajaran agar bisa sesuai dengan metode quiz team yang dieksperimenkan.

Jadwal pelaksanaan penelitian pada kelompok eksperimen secara terperinci adalah sebagai berikut:

Tabel 2. Jadwal Penelitian Kelompok Eksperimen

\begin{tabular}{|c|c|}
\hline Jadwal & Kelompok Eksperimen \\
\hline \multicolumn{2}{|l|}{ Minggu 1} \\
\hline $\begin{array}{l}\text { Pertemuan } 1 \text { (Selasa, } 12 \text { April 2011) } \\
\text { Jam } 08.20 \text { - } 09.00\end{array}$ & $\begin{array}{l}\text { Pemilihan materi (M ateri: Atom). } \\
\text { Pembentukan kelompok (menjadi } 3 \text { kelompok besar). } \\
\text { Penyampain materi atom oleh guru. }\end{array}$ \\
\hline $\begin{array}{l}\text { Pertemuan } 2 \text { (Kamis, } 14 \text { April 2011) } \\
\text { I. Jam 09.55 - } 10.35\end{array}$ & $\begin{array}{l}\text { Diskusi masing-masing kelompok dan Pertandingan } \\
\text { akademis (Quiz team) }\end{array}$ \\
\hline \multicolumn{2}{|l|}{ II. Jam $10.35-11.15$} \\
\hline Pertemuan 3 (Selasa, 19 April 2011) & Pemilihan materi (M ateri: Ion). \\
\hline Jam 08.20 - 09.00 & $\begin{array}{l}\text { Pembentukan kelompok (menjadi } 3 \text { kelompok besar). } \\
\text { Penyampain materi ion oleh guru. }\end{array}$ \\
\hline Pertemuan 4 (Kamis, 21 April 2011) & Diskusi masing-masing kelompok dan Pertandingan \\
\hline I. Jam $09.55-10.35$ & akademis (Quiz team) \\
\hline \multicolumn{2}{|l|}{ II. Jam $10.35-11.15$} \\
\hline \multicolumn{2}{|l|}{ Minggu 3} \\
\hline $\begin{array}{l}\text { Pertemuan } 5 \text { (Selasa, } 26 \text { April 2011) } \\
\text { Jam } 08.20 \text { - } 09.00\end{array}$ & Libur ujian nasional \\
\hline Pertemuan 6 (Kamis, 28 April 2011) & Libur ujian nasional \\
\hline \multicolumn{2}{|l|}{ I. Jam $09.55-10.35$} \\
\hline \multicolumn{2}{|l|}{ II. Jam $10.35-11.15$} \\
\hline \multicolumn{2}{|l|}{ Minggu 4} \\
\hline Pertemuan 7 (Selasa, 3 M ei 2011) & Pemilihan materi (Materi: Molekul). \\
\hline Jam 08.20 - 09.00 & $\begin{array}{l}\text { Pembentukan kelompok (menjadi } 3 \text { kelompok besar). } \\
\text { Penyampain materi molekul oleh guru. }\end{array}$ \\
\hline Pertemuan 8 (Kamis, 5 M ei 2011) & Diskusi masing-masing kelompok dan Pertandingan \\
\hline \multicolumn{2}{|r|}{ akademis (Quiz team) } \\
\hline \multicolumn{2}{|l|}{ II. Jam $10.35-11.15$} \\
\hline \multicolumn{2}{|l|}{ Minggu 5} \\
\hline $\begin{array}{l}\text { Pertemuan } 9 \text { (Selasa, } 10 \text { Mei 2011) } \\
\text { Jam } 08.20 \text { - } 09.00\end{array}$ & Pengulangan materi (M ereview) \\
\hline Pertemuan 10 (Kamis, 12 M ei 2011) & Post-test \\
\hline I. Jam $09.55-10.35$ & \\
\hline II. Jam $10.35-11.15$ & \\
\hline
\end{tabular}


Tabel 3. Jadwal Penelitian Kelompok Kontrol

\begin{tabular}{|c|c|}
\hline Jadwal & Kelompok Kontrol \\
\hline \multicolumn{2}{|l|}{ Minggu 1} \\
\hline Pertemuan 1 (Selasa, 12 April 2011) & Materi dan Tanya Jawab \\
\hline I. Jam $10.35-11.15$ & \\
\hline II. Jam 11.15- 11.55 & \\
\hline $\begin{array}{l}\text { Pertemuan } 2 \text { (Kamis, } 14 \text { April 2011) } \\
\text { Jam } 06.45 \text { - } 07.40\end{array}$ & Materi \\
\hline \multicolumn{2}{|l|}{ Minggu 2} \\
\hline Pertemuan 3 (Selasa, 19 April 2011) & Materi dan Tanya Jawab \\
\hline I. Jam $10.35-11.15$ & \\
\hline II. Jam 11.15- 11.55 & \\
\hline $\begin{array}{l}\text { Pertemuan } 4 \text { (Kamis, } 21 \text { April 2011) } \\
\text { Jam } 06.45 \text { - } 07.40\end{array}$ & Materi \\
\hline \multicolumn{2}{|l|}{ Minggu 3} \\
\hline $\begin{array}{l}\text { Pertemuan } 5 \text { (Selasa, } 26 \text { April 2011) } \\
\text { I. Jam } 10.35-11.15\end{array}$ & Libur ujian nasional \\
\hline $\begin{array}{l}\text { Il. Jam 11.15- } 11.55 \\
\text { Pertemuan } 6 \text { (Kamis, } 28 \text { April 2011) } \\
\text { Jam } 06.45-07.40\end{array}$ & Libur ujian nasional \\
\hline \multicolumn{2}{|l|}{ Minggu 4} \\
\hline $\begin{array}{l}\text { Pertemuan } 7 \text { (Senin, } 2 \text { M ei 2011) } \\
\text { Jam } 12.25-13.05\end{array}$ & Materi dan Tanya Jawab \\
\hline Pertemuan 8 (Sabtu, 7 M ei 2011) & Materi \\
\hline I. Jam $08.20-09.00$ & \\
\hline II. Jam $09.15-09.55$ & \\
\hline \multicolumn{2}{|l|}{ Minggu 5} \\
\hline $\begin{array}{l}\text { Pertemuan } 9 \text { (Senin, } 9 \text { M ei 2011) } \\
\text { Jam } 12.25-13.05\end{array}$ & Pengulangan materi (Mereview) \\
\hline Pertemuan 10 (Sabtu, 14 Mei 2011) & Post-test \\
\hline I. Jam $08.20-09.00$ & \\
\hline II. Jam $09.15-09.55$ & \\
\hline
\end{tabular}

\section{Hasil dan Pembahasan}

Hasil analisis uji normalitas berdasarkan nilai selisih kelompok eksperimen diperoleh $p=$ $0.035(p<0,05)$ yang berarti bahwa sebaran skor subjek kelompok eksperimen tidak normal. Sedangkan, uji normalitas berdasarkan nilai selisih kelompok kontrol diperoleh $p=0.359$ ( $p>$ 0,05 ) yang berarti bahwa sebaran skor subjek kelompok kontrol adalah normal. Hasil analisis uji homogenitas berdasarkan nilai selisih kelompok eksperimen dan kelompok kontrol diperoleh $\mathrm{F}=23.616$ dengan $p=0,000$ yang artinya varians bersifat tidak homogen karena $p$ $(0,000)<0,05$.

Hasil uji t rerata pre-test kedua kelompok menunjukkan bahwa nilai t hitung $=-6.951$ dan $p$ $=0.000$. Artinya adalah perbedaan kemampuan awal yang ada pada subjek dikedua kelompok penelitian bersifat sangat signifikan karena $p(0,000)<0,01$.

Hasil uji hipotesis memperlihatkan bahwa nilai t hitung $=3.103$ dan nilai $p=0,003$. Artinya adalah perbedaan yang ada bersifat sangat signifikan karena $p(0,003)<0,01$. Perbedaan tersebut bisa juga dilihat dari nilai t hitung yang lebih besar dari nilai t-tabel $1 \%(2.660)$ 
maupun t-tabel 5\% (2.000) yang berarti bahwa terdapat perbedaan antara skor prestasi kelompok kontrol dengan skor prestasi kelompok eksperimen dengan sangat signifikan.

Hasil uji asumsi yang dilakukan dalam penelitian ini menunjukkan bahwa skor kelompok eksperimen tersebar dalam distribusi tidak normal, sedangkan skor kelompok kontrol tersebar dalam distribusi normal. Berdasarkan nilai selisih dari setiap kelompok menunjukkan varians bersifat tidak homogen (heterogen). Menurut Hadi (2001) bagi kelompok yang mengartikan asumsi sebagai prasyarat perlu mempersiapkan langkah-langkah alternatif sekiranya ada asumsi atau sejumlah asumsi dari model analisis yang diajukan ternyata tidak terpenuhi. Langkah-langkah alternatif yang banyak dikemukakan adalah (1) mengganti model analisis parametrik yang direncanakan dengan model analisis lain, umumnya analisis nonparametrik, yang setara; (2) tetap menggunakan model analisis yang direncanakan, tetapi membuat interpretasi yang longgar (sering disebut interpretasi konservatif) terhadap hasil analisisnya. Interpretasi yang longgar ini hanya menunjukkan sifat penghati-hati yang lebih besar. Kehatihatian ini mengarah kepada lebih baik menyatakan tidak ada perbedaan atau tidak ada korelasi sekiranya hasil ujinya nyaris pada ambang batas penerimaan dan penolakan hipotesis. Aturannya adalah melipatduakan besar peluang galat alfa $p$ (probability of alpha error $p$ ) dari hasil ujinya, atau menyatakan kesimpulan adanya perbedaan atau korelasi belum kongklusif, tetapi baru indikatif, yang masih memerlukan konfirmasi dalam penelitian-penelitian selanjutnya (Hadi, 2001).

Di karenakan asumsi yang telah diuji ternyata tidak terpenuhi, maka peneliti menggunakan langkah alternatif yang kedua. Yaitu tetap menggunakan model analisis yang direncanakan, tetapi membuat interpretasi yang longgar dengan menyatakan bahwa kesimpulan adanya perbedaan belum kongklusif, tetapi baru indikasi.

Berdasarkan hasil uji t nilai pre-test antara kelompok eksperimen dan kelompok kontrol diperoleh nilai $t$ hitung $=-6.951$ dan $p=0.000(<0.01)$. Hasil perhitungan tersebut menunjukkan bahwa perbedaan rerata pre-test antara kelompok eksperimen dan kelompok kontrol dapat dikatakan sangat signifikan. Hal ini menunjukkan bahwa dari awal kemampuan subjek dikedua kelompok memang sudah berbeda. Dimana rerata pre-test kelompok kontrol lebih tinggi daripada rerata pre-test kelompok eksperimen. Hal ini menunjukkan bahwa terdapat perbedaan proactive history khususnya yaitu kemampuan intelektual dari subjek di masing-masing kelompok. Keadaan awal yang berbeda ini merupakan salah satu penyebab dari tidak terpenuhinya uji homogenitas, dimana kondisi subjek dari kelompok eksperimen dan kelompok kontrol adalah heterogen (berbeda-beda).

Hasil uji t yang dilakukan untuk menguji perbedaan selisih nilai post-test dan pre-test kelompok eksperimen dengan selisih nilai post-test dan pre-test kelompok kontrol. Hasil perhitungan menunjukkan ada indikasi perbedaan yang sangat signifikan antara peningkatan nilai rerata post-test dan pre-test kelompok eksperimen dengan kelompok kontrol pada siswa kelas VIII SM P Islam Sultan Agung 4 Semarang dengan nilai t hitung $=3.103$ dan $p=0,003$.

Berdasarkan hasil hitung pengujian hipotesis tersebut maka dapat dinyatakan bahwa hipotesis yang diajukan diterima, yaitu mengindikasikan terdapat pengaruh active learning terhadap peningkatan prestasi belajar fisika pada siswa kelas VIII SMP Islam Sultan Agung 4 
Semarang. Terbuktinya hipotesis ini bisa dilihat dari adanya perbedaan peningkatan prestasi yang signifikan pada kelompok eksperimen yang diperlakukan menggunakan model pembelajaran active learning dengan kelompok kontrol yang tidak mendapat pembelajaran active learning.

Terbuktinya hipotesis ini juga didukung dari data pre-test dan post-test kelompok kontrol yang menggunakan pembelajaran ceramah, tanya jawab serta penugasan, mengalami penurunan rerata. Hal ini dibuktikan setelah dilakukan uji t, diperoleh nilai t hitung $=-1.364$ dan $p=0.177$ ( $>0.05)$ yang artinya bahwa perbedaan rerata pre-test dan post-test kelompok kontrol tidak signifikan. Sedangkan, kelompok eksperimen yang menggunakan model pembelajaran active learning mengalami kenaikan rerata. Hal ini dibuktikan dari data pre-test dan post-test kelompok eksperimen yang diuji $t$, dimana diperoleh nilai t hitung $=2.665$ dan $p$ $=0.010(<0.05)$ yang artinya bahwa perbedaan rerata pre-test dan post-test kelompok eksperimen terhitung signifikan. Ini berarti sebenarnya walaupun tanpa menggunakan pembandingan dengan kelompok kontrol rerata pada kelompok eksperimen sendiri telah mengalami kenaikan yang sangat berarti.

Hal di atas diperkuat dengan penelitian terdahulu dari Nurhayati (2007) yang menunjukkan bahwa pengaruh pembelajaran aktif tipe quiz team terhadap hasil belajar akuntansi menunjukkan bahwa nilai hasil belajar pada kelompok eksperimen lebih baik daripada nilai hasil belajar pada kelompok kontrol. Hal ini dapat dilihat selama proses pembelajaran pada kelas eksperimen menggunakan pembelajaran aktif tipe quiz team yaitu diskusi kelompok dan pertandingan akademis. Sedangkan, proses pembelajaran pada kelompok kontrol menggunakan pembelajaran konvensional dengan metode ceramah dan latihan soal. Penerapan metode belajar aktif tipe quiz team memberikan peningkatan keaktifan siswa dalam proses belajar. Keaktifan ini merupakan keinginan siswa untuk bertanya ataupun menjawab materi kepada sesama kelompok atau dengan kelompok lain. Sehingga suasana kelas lebih hidup dan siswa bersemangat dalam proses pembelajaran.

Pada saat diskusi kelompok, setiap kelompok mempelajari materi dan menjawab pertanyaan yang diberikan oleh guru. Sedangkan, ketika pertandingan akademis setiap kelompok mendapat lembar jawab yang digunakan untuk menulis dan menjawab pertanyaan dari kelompok pemandu kuis. Ketika menjawab pertanyaan, perwakilan dari kelompok memberikan jawabannya dengan keras supaya kelompok lain mengetahui jawaban tersebut benar atau salah. Setiap jawaban yang benar mendapatkan nilai 50 dan setiap jawaban salah mendapat nilai 0 . Setelah pertandingan akademsi selesai, guru memberikan kesimpulan materi dan memberitahukan perolehan nilai setiap kelompok. Berikut hasil pertandingan akademis yang di dapat dari setiap kelompok: 
Tabel 4. Perolehan Nilai Pertandingan Akademis Setiap Kelompok

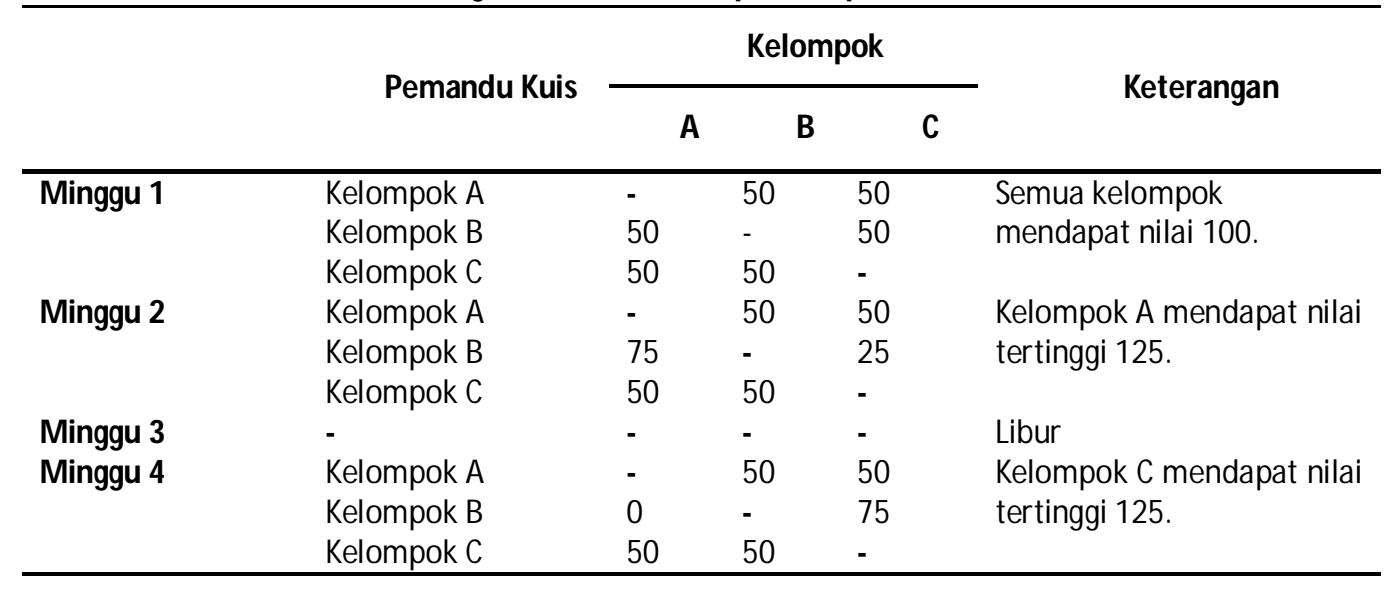

\section{Kesimpulan dan Saran}

Kesimpulan

Berdasarkan hasil penelitian dan pembahasan di atas, maka dapat di indikasikan bahwa model pembelajaran active learning dapat meningkatkan prestasi belajar fisika pada siswa kelas VIII SM P Islam Sultan Agung 4 Semarang dengan sangat signifikan.

Saran

Bagi para guru dan pihak-pihak yang terkait, agar dapat menerapkan model pembelajaran active learning ini dalam proses belajar mengajar. Sehingga prestasi belajar siswa dapat meningkat dan siswa juga mendapatkan suasana belajar yang aktif.

Bagi peneliti selanjutnya agar dapat mengontrol berbagai variabel ekstrane yang belum dapat terkontrol dalam penelitian ini. Salah satu variable ekstrane yang penting misalnya adalah menyamakan ruang dan waktu penelitian dengan menyediakan ruangan khusus untuk eksperimen, waktu yang disediakan tidak harus dalam jam yang sama tetapi lebih pada kondisi yang serupa. Selain itu, jumlah siswa di kedua kelompok penelitian diharapkan dalam jumlah yang sama. Hasil yang lebih baik sangat mungkin akan diperoleh jika penelitian bisa dilaksanakan pada dua kelas utuh yang setara tingkatnya, dengan mata pelajaran dan pengajar yang sama, dilaksanakan dalam ruang khusus yang sama, serta pada waktu yang relatif sama.

\section{Daftar Pustaka}

Ahmadi, A., \& Supriyono, W. (1991). Psikologi Belajar. Jakarta: PT. Rineka Cipta

Al-Jawi, M. S. (2006). Pendidikan di Indonesia: Masalah dan Solusinya. Diunduh, 9 Oktober 2010, dari http:// www.khilafah1924.org/index2.php?option=com_content\&do_pdf=1\&id=227

Azwar, S. (1999). Pengantar Psikologi Inteligensi. Yogyakarta: Pustaka Pelajar 
Dalvi. (2006). Upaya Meningkatkan Keaktifan Belajar Siswa Dalam Pembelajaran Agama Dengan Menggunakan Metode Belajar Aktif Tipe Kuis Tim Di Kelas VI.B MI Diniyah Puteri Padang Panjang Semester Ganjil Tahun Pelajaran 2005/2006. Jurnal Guru, 3 (1), 59-69. Diunduh, 24 November 2010, dari http://jurnal.pdii.lipi.go.id/admin/jurnal/31065969.pdf

Hadi, S. (2001). Isu Uji Asumsi. Buletin Psikologi, Tahun IX (1). Diunduh 28 Juli, 2011, dari www.ugm.ac.id

Hartono. (2008). Strategi Pembelajaran Active Learning. Diunduh, 5 April 2010, dari www.wordpress.com

Kumara, A. (2004). Model Pembelajaran "Active Learning" Mata Pelajaran Sains Tingkat SD Kota Yogyakarta Sebagai Upaya Peningkatan "Life Skills". Jurnal Psikologi, 2, 63-91. Yogyakarta: Universitas Gajah Mada

Nurhayati, E. (2007). Pengaruh Penggunaan Metode Belajar Aktif Tipe Quiz Team Terhadap Minat Belajar Dan Hasil Belajar Akuntansi Siswa Kelas X AK SMK Negeri 3 Jepara Tahun 2006/2007. Skripsi (tidak diterbitkan). Semarang: Fakultas Ekonomi Universitas Negeri Semarang

Rosada, A., \& Kumara, A. (2004). Efektivitas Model Pembelajaran Aktif Untuk Meningkatkan Kompetensi Siswa Kelas V Sekolah Dasar Pada Mata Pelajaran IImu Pengetahuan Alam. Jurnal Psikologi, 2, 142-157. Yogyakarta: Universitas Gajah M ada

Siregar, H. (2003). Peranan Fisika Pada Disiplin IImu Teknik Kimia. Sumatra Utara: Fakultas Teknik Program Teknik Kimia Universitas Sumatra Utara. Diunduh, 14 Desember 2010, dari http://library.usu.ac.id/download/ft/tkimia-harrys2.pdf

Surya, M. (2004). Psikologi Pembelajaran Dan Pengajaran. Bandung: Pustaka Bani Quraisy

Suryabrata, S. (2004). Psikologi Pendidikan. Jakarta: Rajawali Pers

Syah, M. (2001). Psikologi Belajar. Jakarta: Logos

Widyastuti, E., \& Kuswardani, I. (2008). Hubungan Antara Harga Diri Dan Prestasi Belajar Fisika Pada Siswa STM . Psikohumanika, 1(1), 22-29. Surakarta: Fakultas Psikologi Universitas Setia Budi

Wikipedia Indonesia, ensiklopedia bebas berbahasa Indonesia. (2010). Fisika. Diunduh, 31 Oktober 2010, dari http://id. wikipedia.org/wiki/ Fisika

Winkel, W. S. (1996). Psikologi Pengajaran. Jakarta: PT.Grasindo

Zaini, H., M unthe, B., \& Aryani, S. A. (2007). Strategi Pembelajaran Aktif. Yogyakarta: CTSD Institut Agama Islam Negeri Sunan Kalijaga 